\title{
Long Term Effect of Inorganic and Organic Sources of Nutrients on Soil Physical Properties and Productivity of Direct Seeded Rice (Oryza sativa L.) - MTU1010 under Rainfed Midland Situation at Bastar Palteau Zone
}

\author{
Deepika Sahu", T. Chandrakar, A. Pradhan, D. P. Singh, Purnima Sahu, Madhuri \\ Dapake, Janak Ram Pali and Danish Ahemad Siddiqui
}

Shaheed Gundadhur College of Agriculture and Research Station, Kumhrawand, Jagdalpur-494005, Chhattisgarh (India)

*Corresponding author

\section{A B S T R A C T}

\begin{tabular}{|l|} 
Ke y w or d s \\
$\begin{array}{l}\text { Manure, Fertilizer, } \\
\text { Physico-chemical } \\
\text { properties, LTFE, } \\
\text { Yield, Fertility }\end{array}$ \\
\hline Article Info \\
\hline $\begin{array}{l}\text { Accepted: } \\
\text { 15 September } 2020 \\
\text { Available Online: } \\
10 \text { October } 2020\end{array}$ \\
\hline
\end{tabular}

\section{Introduction}

In India a pride place is occupied by rice (Oryza sativa L.) among all the food crops cultivated. India is among one of the largest producers in the world for agricultural production. It ranks second in the world for rice production. Very large amount of nutrient removal from Indian soil taken place in these years due to involving high yielding rice varieties within intensive agriculture. It can be seen increase in application of inorganic nutrient sources day by day enabling soil to
A long term field experiment was conducted since kharif 2015 for evaluating the effect of inorganic and organic sources of nutrients on soil physical properties and productivity on direct seeded rice ( Oryza satia L.) - MTU1010 under rainfed midland situation at Bastar plateau zone at S. G. College of Agriculture and Research Station, Jagdalpur, Chhattisgarh. Random block design was used with twelve treatments and four replications to carry out experiment. The full recommended dose of fertilizer for rice crop was $100 \mathrm{~kg}$ $\mathrm{ha}^{-1}$ Nitrogen, $60 \mathrm{~kg} \mathrm{ha}^{-1}$ phosphorus and $40 \mathrm{~kg} \mathrm{ha}^{-1}$. For analysis of physical properties soil sample was collected from soil depth of $15 \mathrm{~cm}$ and $30 \mathrm{~cm}$ in all the experimental treatments and for analysis nutrient content sample was collected from $(0-15 \mathrm{~cm})$ top soil surface before and after kharif 2019. FYM along with 100\% RDF plus lime 3 q/ha and ZnSO4@ $25 \mathrm{~kg} / \mathrm{ha}$ over six years of continued application resulted significant increase in $\mathrm{K}$ and WHC and decrease in BD and hence resulted in productivity of rice. 
Agriculture and Research Station Jagdalpur, village Kumhrawand, District Bastar, State Chhattisgarh. The experiment was conducted in random bock design with twelve treatments which were $\mathrm{T}_{1}$ control, $\mathrm{T}_{2} \quad 100 \%$ recommended dose of fertilizer $(100: 60: 40 \mathrm{~kg}$ $\left.\mathrm{ha}^{-1}\right), \mathrm{T}_{3}(100 \% \quad \mathrm{PK}), \mathrm{T}_{4}(100 \% \quad \mathrm{NK}), \mathrm{T}_{5}$ $(100 \% \mathrm{NP}), \mathrm{T}_{6}(100 \% \mathrm{NPK}+5$ t $\mathrm{FYM}), \mathrm{T}_{7}$ $\left(100 \% \mathrm{NPK}+5 \mathrm{t} \mathrm{FYM} \mathrm{+} \mathrm{ZnSO}_{4} @ 25 \mathrm{~kg} \mathrm{ha}^{-1}\right)$, $\mathrm{T}_{8}\left(100 \% \mathrm{NPK}+5 \mathrm{t} \mathrm{FYM}+\mathrm{ZnSO}_{4} @ 25 \mathrm{~kg} \mathrm{ha}^{-1}\right.$ + Lime $\left.3 \mathrm{q} \mathrm{ha}^{-1}\right), \mathrm{T}_{9}(50 \% \mathrm{NPK}), \mathrm{T}_{10}(50 \%$ $\mathrm{NPK}+5$ t FYM $), \mathrm{T}_{11}(50 \% \mathrm{NPK}+5 \mathrm{t} \mathrm{FYM+}$ $\left.\mathrm{ZnSO}_{4} @ 25 \mathrm{~kg} \mathrm{ha}^{-1}\right)$ and $\mathrm{T}_{12}(50 \% \mathrm{NPK}+5 \mathrm{t}$ FYM+ ZnSO $@$ @25kg ha ${ }^{-1}+$ Lime $3 \mathrm{q} \mathrm{ha}^{-1}$ ) replicated four times. Soil $\mathrm{pH}, \mathrm{EC}, \mathrm{OC}$, available NPKS determined in the laboratory by standard procedures. Soil Physical properties such as BD, WHC and hydraulic conductivity were determined in-situ using standard instruments and procedures. Hydraulic conductivity of each treatment was estimated using Guelph permeameter kit model 2800K1, Eijkelkamp (www.eijkelkamp.com/Guelphpermeameter). At depth of $15 \mathrm{~cm}$ and $30 \mathrm{~cm}$ each six readings were taken and at 5 and $10 \mathrm{~cm}$ water head. Using the formula, hydraulic conductivity of each treatment is calculated as

$\mathrm{K}=(0.0041)(\mathrm{X})(0.56)-(0.0054)\left(\mathrm{X}^{\prime}\right)(0.63)$

Here,

$\mathrm{K}$ is hydraulic conductivity in $\mathrm{cm} / \mathrm{sec}$ and $\mathrm{X}$ and $X^{\prime}$ are the average value of steady state rate of flow in $\mathrm{cm} / \mathrm{sec}$ taken at $10 \mathrm{~cm}$ and 5 $\mathrm{cm}$ water head respectively.

\section{Results and Discussion}

\section{Bulk density at 15 and $30 \mathrm{~cm}$ soil depth}

The application of organic manure i.e. FYM along with inorganic fertilizer lead to achieve significant effect on soil bulk density. Soil bulk density of treatments with $15 \mathrm{~cm}$ soil depth ranges from 1.35 to $1.47(\mathrm{~g} / \mathrm{cc})$ as shown in Table 1. The highest value (1.47 $\mathrm{g} / \mathrm{cc})$ of bulk density was observed in $\left(\mathrm{T}_{3}\right)$ $100 \% \mathrm{PK}$ and $\left(\mathrm{T}_{5}\right) 100 \% \mathrm{NP}$ while the lowest value $(1.35 \mathrm{~g} / \mathrm{cc})$ of bulk density was recorded in $\left(\mathrm{T}_{6}\right) \quad 100 \% \mathrm{NPK}+5 \mathrm{t}$ FYM. Bulk density of soil helps in aeration as well as proper movement of water in soil. It provides structural support to plant. More compact soil shows high value of bulk density than others. In treatment $\left(\mathrm{T}_{6}\right) 100 \% \mathrm{NPK}+5 \mathrm{t} \mathrm{FYM}$ the incorporation of organic manure lead to decrease the bulk density of soil. Treatments incorporated with organic manure $\mathrm{T}_{6}, \mathrm{~T}_{7}, \mathrm{~T}_{8}$, $\mathrm{T}_{10}, \mathrm{~T}_{11}$ and $\mathrm{T}_{12}$ have shown significant decrease in soil bulk density as compared to plot treated alone with the inorganic fertilizers. The range of bulk density among different treatments at the soil depth of $30 \mathrm{~cm}$ ranges from $1.50\left(\mathrm{~T}_{11}\right)$ to $1.57(\mathrm{~g} / \mathrm{cc})\left(\mathrm{T}_{2}\right)$. The maximum value $(1.57 \mathrm{~g} / \mathrm{cc})$ of soil bulk density is recorded in $100 \%$ NPK $\left(\mathrm{T}_{2}\right)$ where as the minimum value $(1.50 \mathrm{~g} / \mathrm{cc})$ of soil bulk density is estimated in 50\% NPK + $5 \mathrm{t} \mathrm{FYM+}$ $\mathrm{ZnSO}_{4} @ 25 \mathrm{~kg} \mathrm{ha}^{-1}\left(\mathrm{~T}_{11}\right)$. In $\mathrm{T}_{11}$ the application of inorganic manure along with chemical fertilizers has shown significant effect on bulk density. The addition of organic manure in soil along with inorganic fertilizers reduces the compactness and increase microbial activity. The results are in agreement with the findings of Athira et al., (2019).

\section{Hydraulic conductivity at depth 15 and 30 cm soil depth}

Data reveals that the addition of FYM with chemical fertilizer enhances the hydraulic conductivity of soil by better particle aggregation. The range of hydraulic conductivity among different treatments was recorded from $3.45 \times 10^{-3} \mathrm{~cm} / \mathrm{sec}$ in $\left(\mathrm{T}_{3}\right) 100 \%$ PK to $5.94 \times 10^{-3} \mathrm{~cm} / \mathrm{sec}$ in $\left(\mathrm{T}_{8}\right) 100 \% \mathrm{NPK}+5$ t FYM+ ZnSO $@ 25 \mathrm{~kg} \mathrm{ha}^{-1}+$ Lime $3 \mathrm{q} \mathrm{ha}^{-1}$. The highest value $\left(5.94 \times 10^{-3} \mathrm{~cm} / \mathrm{sec}\right)$ of hydraulic conductivity was observed in $100 \%$ 
$\mathrm{NPK}+5$ t FYM+ ZnSO $@ 25 \mathrm{~kg} \mathrm{ha}^{-1}+$ Lime 3 $\mathrm{q} \mathrm{ha}^{-1}\left(\mathrm{~T}_{8}\right)$ while the lowest value $\left(3.46 \times 10^{-3}\right.$ $\mathrm{cm} / \mathrm{sec}$ ) of hydraulic conductivity was observed in $\left(\mathrm{T}_{3}\right) 100 \% \mathrm{PK}$. In treatment $\mathrm{T}_{8}$ the addition of organic manure shows statistically significant effect on hydraulic conductivity. Maximum value $\left(5.97 \times 10^{-4} \mathrm{~cm} / \mathrm{sec}\right)$ of hydraulic conductivity for soil at the depth of $30 \mathrm{~cm}$ was recorded in 50\% NPK + $5 \mathrm{t} \mathrm{FYM+}$ $\mathrm{ZnSO}_{4} @ 25 \mathrm{~kg} \mathrm{ha}^{-1}+$ Lime $3 \mathrm{q} \mathrm{ha}^{-1}\left(\mathrm{~T}_{12}\right)$ and $100 \% \mathrm{NPK}+5 \mathrm{t}$ FYM $\left(\mathrm{T}_{6}\right)$. The lowest value of hydraulic conductivity $\left(5.42 \times 10^{-4} \mathrm{~cm} / \mathrm{sec}\right)$ for $30 \mathrm{~cm}$ soil depth was recorded in $100 \%$ NPK $\left(T_{2}\right)$. As compared to other treatments, the treatments $T_{12}$ and $T_{6}$ value of hydraulic conductivity was recorded the highest clearly shows that, the application of lime and FYM have been recorded to gave statistically significant influence on hydraulic conductivity when incorporated with inorganic fertilizers. But in case of other treatments $\left(T_{2}, T_{3}, T_{4}\right.$ and $\left.T_{5}\right)$ where the inorganic fertilizers are incorporated alone the value of hydraulic conductivity was low. Katkar et al., (2012) and Angelova et al., (2013) concluded that the soil physical properties such as hydraulic conductivity was positively affected with the addition of tested organic amendments.

Table.1 Effect of manure and fertilizer on soil physical properties

\begin{tabular}{|c|c|c|c|c|c|c|}
\hline Treatment & $\begin{array}{c}\text { WHC at } \\
15 \mathrm{~cm}(\%)\end{array}$ & $\begin{array}{c}\text { WHC at } \\
30 \mathrm{~cm}(\%)\end{array}$ & $\begin{array}{c}\text { BD }(\mathrm{g} / \mathrm{cc}) \\
\text { at } 15 \mathrm{~cm} \\
\text { depth }\end{array}$ & $\begin{array}{l}\mathrm{BD}(\mathrm{g} / \mathrm{cc}) \\
\text { at } 30 \mathrm{~cm} \\
\text { depth }\end{array}$ & $\begin{array}{c}\text { HC }(k) \text { at } \\
15 \mathrm{~cm} \\
\operatorname{depth}(x \\
10^{-3} \\
\mathrm{~cm} / \mathrm{sec})\end{array}$ & $\begin{array}{c}\text { HC (k) at } \\
30 \mathrm{~cm} \\
\operatorname{depth}(x \\
10^{-4} \\
\mathrm{~cm} / \mathrm{sec})\end{array}$ \\
\hline Control & 35.70 & 29.16 & 1.40 & 1.56 & 3.52 & 5.46 \\
\hline $100 \%$ NPK & 34.06 & 28.74 & 1.45 & 1.57 & 3.61 & 5.42 \\
\hline $100 \% \mathrm{PK}$ & 33.88 & 27.97 & 1.47 & 1.55 & 3.46 & 5.51 \\
\hline $100 \% \mathrm{NK}$ & 33.79 & 28.15 & 1.44 & 1.56 & 3.71 & 5.49 \\
\hline $100 \% \mathrm{NP}$ & 34.17 & 28.16 & 1.47 & 1.55 & 3.86 & 5.48 \\
\hline $100 \% \mathrm{NPK}+5 \mathrm{t}$ FYM & 37.55 & 30.98 & 1.35 & 1.50 & 4.99 & 5.97 \\
\hline $\begin{array}{l}\text { 100\% NPK+5tFYM+Z } \\
\text { nSo }_{4} @ 25 \mathrm{~kg} \mathrm{ha}^{-1}\end{array}$ & 36.46 & 29.91 & 1.39 & 1.52 & 5.24 & 5.79 \\
\hline 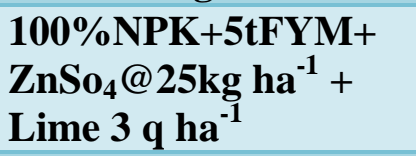 & 37.11 & 30.25 & 1.36 & 1.52 & 5.94 & 5.58 \\
\hline $50 \%$ NPK & 35.98 & 29.53 & 1.46 & 1.51 & 3.68 & 5.87 \\
\hline 50\%NPK + 5t FYM & 37.07 & 30.21 & 1.40 & 1.54 & 4.63 & 5.72 \\
\hline $\begin{array}{l}\text { 50\% NPK + 5tFYM+ } \\
\mathrm{ZnSo}_{4} @ 25 \mathrm{~kg} \mathrm{ha}^{-1}\end{array}$ & 37.03 & 30.68 & 1.37 & 1.50 & 4.95 & 5.87 \\
\hline $\begin{array}{l}\text { 50\% NPK + 5tFYM+ } \\
\text { ZnSo }_{4} @ 25 \mathrm{~kg} \mathrm{ha}^{-1}+ \\
{\text { Lime } 3 \mathrm{q} \mathrm{ha}^{-1}}^{-1}\end{array}$ & 37.50 & 30.58 & 1.39 & 1.51 & 5.21 & 5.97 \\
\hline $\mathrm{CD}(5 \%)$ & 6.10 & 6.05 & 1.03 & 1.07 & 1.04 & 2.41 \\
\hline CD (1\%) & 8.20 & 8.12 & 1.39 & 1.44 & 2.81 & 3.25 \\
\hline CV \% & 11.83 & 14.24 & 5.1 & 5.0 & 16.289 & 15.39 \\
\hline
\end{tabular}


Fig.1 Effect of manures and fertilizers on yield of rice

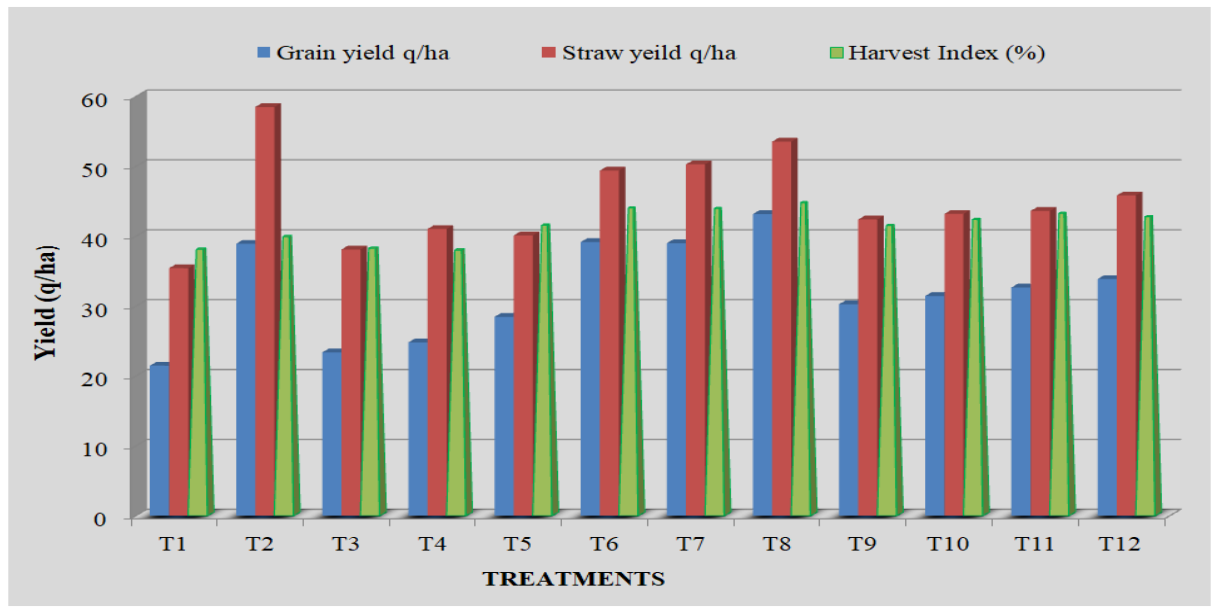

Water holding capacity at soil depth of 15 and $30 \mathrm{~cm}$

Application of organic manure along with inorganic fertilizer had influenced the water holding capacity of soil to a significant level. Treatments where FYM and lime was applied show increase in the value of water holding capacity. While the other treatments in which inorganic fertilizers were applied alone had low value of water holding capacity than those treatments in which integrated form of inorganic fertilizers and organic manures was applied. The ranges of water holding capacity among different treatments are from 33.79 to $37.55 \%$ (weight/weight). treatment $\mathrm{T}_{4}(100 \%$ NK) show lowest value (33.79\%) of water holding capacity at soil depth of $15 \mathrm{~cm}$. the maximum value $(37.55 \%)$ of soil water holding capacity was observed in $100 \%$ $\mathrm{NPK}+5$ t $\mathrm{FYM}\left(\mathrm{T}_{6}\right)$ followed by value $37.50 \%$ in $\mathrm{T}_{12}(50 \% \mathrm{NPK}+5 \mathrm{t} \mathrm{FYM}+$ $\mathrm{ZnSO}_{4} @ 25 \mathrm{~kg} \mathrm{ha}^{-1}+$ Lime 3 q ha $\left.{ }^{-1}\right)$. The results are in similar with the findings of Vegandaramana et al., (2012). Water holding capacity at soil depth of $30 \mathrm{~cm}$ ranges from 27.97 to $30.98 \%$ weight by weight. Maximum value $(30.98 \%)$ of water holding capacity was recorded in $100 \% \mathrm{NPK}+5 \mathrm{t}$ FYM $\left(\mathrm{T}_{6}\right)$. While the treatment having lowest value of water holding capacity is $100 \%$ PK
$\left(T_{3}\right)$. The integrated application of FYM along with inorganic fertilizers had shown increase in water holding capacity of soil. The addition of organic matter along with other chemical fertilizers showed significant changes it is because the organic matter increases quantity of macropores and micropores in the soil by the effect of microbial activity. The similar findings on rice have also been reported by Reicosky (2015).

\section{Grain yield}

Application of organic manures and inorganic fertilizers in combine form exhibited significant effect on the grain yield of rice (Fig. 1). The variation in grain yield among different concentration of fertilizer nutrients alone and along with organic manure lies in a range of 21.50 to $43.20 \mathrm{q} \mathrm{ha}^{-1}$. Highest amount of grain yield $\left(43.20 \mathrm{q} \mathrm{ha}^{-1}\right)$ obtained in 100\% NPK+5 t FYM+ ZnSO ${ }_{4} @ 25 \mathrm{~kg} \mathrm{ha}^{-1}+$ Lime $3 \mathrm{q} \mathrm{ha}^{-1}\left(\mathrm{~T}_{8}\right)$. This may be due optimum soil properties with RDF and organic manure $100 \% \mathrm{NPK}+5$ t FYM+ ZnSO $@ 25 \mathrm{~kg} \mathrm{ha}^{-1}+$ Lime $3 \mathrm{q} \mathrm{ha}^{-1}$ altogether lead to higher grain yield.

The application of inorganic fertilizer along with organic manure (FYM) shows an integrated effect which is more beneficial 
than using only chemical fertilizers. Significant increase in grain yield is visible due to integration of FYM along with inorganic chemical fertilizers. The $50 \%$ doses of RDF with FYM alone or with incorporation of lime and zinc sulphate resulted in additional increase in grain yield in comparison to only inorganic fertilizer treatment and control plots. Similar findings were resulted by Urkurkar et al., (2010).

\section{Straw yield}

The significant effect of different treatments on straw yield of rice crop is indicated by the data presented on Fig. 1. The range of straw yield of rice crop varies from 35.45 to 58.516 $\mathrm{q} \mathrm{ha}{ }^{-1}$. The maximum amount of straw yield (58.516 q ha ${ }^{-1}$ ) was recorded in $100 \%$ NPK (100:60:40 kg ha $\left.{ }^{-1}\right)\left(\mathrm{T}_{2}\right)$ while the minimum straw yield (35.45 $\left.\mathrm{q} \mathrm{ha}^{-1}\right)$ was recorded in control $\left(\mathrm{T}_{1}\right)$ plot. Treatment $100 \%$ NPK (100:60:40 $\left.\mathrm{kg} \mathrm{ha}{ }^{-1}\right) \quad\left(\mathrm{T}_{2}\right)$ was found statistically at par with $100 \% \mathrm{NPK}+5 \mathrm{t}$ FYM+ $\mathrm{ZnSO}_{4} @ 25 \mathrm{~kg} \mathrm{ha}^{-1}\left(\mathrm{~T}_{7}\right)$ and $100 \% \mathrm{NPK}+5 \mathrm{t}$ $\mathrm{FYM}+\mathrm{ZnSO}_{4} @ 25 \mathrm{~kg} \mathrm{ha}^{-1}+$ Lime $3 \mathrm{q} \mathrm{ha}^{-1}\left(\mathrm{~T}_{8}\right)$ with $50.313 \mathrm{q} \mathrm{ha}^{-1}$ and $53.563 \mathrm{q} \mathrm{ha}^{-1}$ respectively but $\left(\mathrm{T}_{2}\right)$ was superior than rest of the treatments. Incorporation of FYM with RDF, zinc sulphate and lime in favorable condition improved straw yield of rice crop. Similar findings were reported by Alim (2012) and Sahu (2018). No significant difference obtained in case of harvest index.

In conclusion long term application of organic and inorganic sources of nutrients in an integrated form resulted to influence the soil physical properties such as BD, hydraulic conductivity and water holding capacity in a significant level. FYM along with $100 \%$ RDF plus lime 3 q/ha and ZnSO4 @ 25 kg/ha over six years of continued application resulted significant increase in $\mathrm{K}$ and $\mathrm{WHC}$ and decrease in $\mathrm{BD}$ and hence resulted in productivity of rice.

\section{Acknowledgement}

We are thankful to All India Coordinated Research Project for Dryland Agriculture, SG College of Agriculture and Research Station, Jagdalpur centre for providing the support during the study.

\section{References}

Alim, M. A. 2012. Effect of organic and inorganic sources and doses of nitrogen fertilizer on the yield of Boro rice. J. Environ. Sci. \& Natural Res. 8(1): 76-80.

Angelova, V. R., V. I. Akova, N. S. Artinova and K. I. Ivanov, 2013. The effect of organic amendments on soil chemical characteristics. Bulg. J. Agric. Sci., 19: 958-971.

Athira M, R. Jagadeeswaran and R. Kumaraperumal, 2019. Influence of soil organic matter on bulk density in Coimbatore soils, International Journal of Chemical Studies; 7(3): 3520-3523.

Katar, R.N., Kharche, V.K., Sonune, B.A., Wanjari, R.H., and Muneshwar Singh 2012. Long term effect of nutrient management on soil quality and sustainable productivity under sorghum- wheat crop sequence in vertisol of Akola, Maharashtra, Agropedology, 22(2), 103-114.

Reicosky, D.C., 2015. Conservation tillage is not conservation agriculture. Journal of Soil and Water Conservation. 70(5):103A-108A.

Sahu, P., Chandrakar T., Paikra M. and Joshi K. K. 2018. Effect of Organic and Inorganic Sources of Nutrients on Yield Attributing Characters and Yield of Direct Seeded Rice in Inceptisols of Bastar Plateau Zone. International Journal of Current Microbiology and Applied Sciences. 
7(3): 3757-3661.

Urkurkar, J.S., Tiwari, A., Shrikanth Chitale and Bajpai, R.K. 2010. Influence of long term use of inorganic and organic manures on soil fertility and sustainable productivity of rice (Oryza sativa) and Wheat (Triticum aestivum) in Inceptisols. Indian J. of Agril. Sci. 80. (3): 208-212.
Vengadaramana, A., Jashothan and J P.T. 2012. Effect of organic fertilizers on the water holding capacity of soil in different terrains of Jaffna peninsula in Sri Lanka, J. Nat. Prod. Plant Resource, 2 (4):500-503. www.eijkelkamp.com/Guelphpermeameter.

\section{How to cite this article:}

Deepika Sahu, T. Chandrakar, A. Pradhan, D. P. Singh, Purnima Sahu, Madhuri Dapake, Janak Ram Pali and Danish Ahemad Siddiqui. 2020. Long Term Effect of Inorganic and Organic Sources of Nutrients on Soil Physical Properties and Productivity of Direct Seeded Rice (Oryza sativa L.) - MTU1010 under Rainfed Midland Situation at Bastar Palteau Zone. Int.J.Curr.Microbiol.App.Sci. 9(10): 1678-1683. doi: https://doi.org/10.20546/ijcmas.2020.910.202 